\title{
Institutional audit regulation in Russia in conditions of sustainable development
}

\author{
Natalia $\mathrm{Kim}^{1, *}$ \\ ${ }^{1}$ Chelyabinsk State University, 129, Br.Kashirinykh str., 454001, Chelyabinsk, Russia
}

\begin{abstract}
This article considers the need to rethink the content and scope of the state's coordinating functions in the field of audit; The article pays attention to the lack of development of the institutional aspects of audit; the need to expand the theoretical and methodological tools of audit, which allows to determine the impact of economic and legal support factors on the management decisions of users of reporting. The purpose of the article is to formulate the institutional problems of audit and on their basis to substantiate the theoretical and methodological foundations for improving the institute of auditing, including the Russian one. The scientific novelty of the research lies in the interdisciplinary consideration of issues involving the works of philosophers and jurists. The study substantiates the truth of the audit, which consists in determining the reliability of financial statements, defines the boundaries covered by the audit relationship, imperative and dispositive legal norms in the field of auditing.
\end{abstract}

\section{Introduction}

Audit is implemented in the public-legal and private-legal spheres of the company, in connection with which it acquires the status of a systemic economic and legal phenomenon. The development of market relations in Russia persistently displaces audit in the sphere of civil society activity, frees it from excessive guardianship by the state and involves a gradual transformation into public audit associations that independently adjust professional standards. The public-legal aspect as a result of this process will be implemented in the establishment by the state of the general legal principles of audit and supervisory functions, and the private-legal aspect-in the establishment of civil society.

The Russian audit, being an economic and legal institution, should become a guarantor of the Russian economy's entry to a qualitatively new level.

Thus, the relevance of this study is determined by the following:

- the need to rethink the content and scope of the coordinating functions of the state in the field of audit;

- insufficient development of the institutional aspects of the audit;

- the need to expand the theoretical and methodological tools of the audit, which allows us to determine the impact of economic and legal support factors on the management decision-making by users of the report

The most important thing in the theory of audit is the concept of reliability of financial

* Correspondibg author: kimnv13@yandex.ru 
statements based on materiality, which we understand as a criterion for the truth of the audit. The principle of materiality in the audit is a kind of foundation, a guarantee for the expression of professional opinion and is used in solving many problems [98]. It forms a logical relationship between the stages of the audit, the scope and content of the audit procedures, the evaluation of the results of the audit evidence collected, and the form of the audit report. On the question of determining materiality, various points of view are expressed by $[\ldots]$

However, the recommended methods for calculating the level of materiality in mandatory audit, which are used in most audit firms, and the methods used in practice for determining materiality, have serious shortcomings, the analysis of which is devoted to the work of a number of specialists in the field of audit theory and practice $[1,8]$..

The main disadvantage of these methods is the lack of connection with the general concept of audit, which is based on the interests of users of the reports. In addition, there is no logical and empirical justification for the set of economic basic reporting indicators, as well as the shares applied to these indicators for calculating the level of materiality. These shortcomings significantly reduce the effectiveness of the use of methods in practice and can negatively affect the truth of the audit

The specifics of the formation of the Russian audit in the conditions of strict state regulation of audit activities have affected the development of the regulatory framework and the methodological basis of many problematic issues of the development of not only the practice, but also the theory of audit.

The redistribution of functions of regulation of audit activities between the public authorities and self-regulatory organizations, the lack of a theoretical basis for the solution of problems related to state and public regulation of auditing, underscores the importance of considering issues of theory and methodology in their logical relationships that are reflected in $[2,3]$

Most theoretical, methodological and technical problems of the audit related to unresolved legal issues, in particular, the specifics of legal regulation of audit activities, the legal mechanism for the implementation of the law on audit issues mandatory and discretionary rules in audit, legal audit and evaluation etc.

Thus, the range of audit problems identified by us and the analysis of ways to solve them allows us to reach a new level of theoretical and applied research in the field of audit, which, in turn, is of great national economic importance.

The relevance of the problems posed, their theoretical, methodological and practical significance, the presence of a number of unresolved and debatable issues determined the choice of the research topic and its purpose.

The purpose of the study to formulate the institutional problems of audit and on their basis to substantiate the theoretical and methodological foundations for improving the Russian institute of audit.

\section{Materials and methods}

The research is carried out on the basis of the general theoretical (philosophical) method, specific-applied methods, methods of predictive analysis and special methods. In modern scientific research, the normative element noticeably prevails. Normative methodological knowledge, acting in the form of prescriptions and norms that define the content and sequence of certain types of activities, performing numerous important functions, provided the formulation of problems from both a substantive and a formal point of view. Used in the study the method of legal regulation as an institutional aspects of the audit, which is the ordering and the establishment of elements of reality, allowed to set boundaries covered by the audit relationship, the techniques and methods of identifying the rights and 
responsibilities of entities regulated economic and legal relations, to determine the imperative and dispositive legal norms in the field of auditing.

This made it possible to obtain a complete structure of the audit as an integral culturalhistorical, socio-economic and legal phenomenon.

At the heart of any fragment of objective and subjective reality, including audit, is the principle of institutionality, the content of which is the establishment, ordering of the elements of reality. Without focusing on the economic, social, cultural-historical, informational and organizational elements of the audit in this article, we will consider other important institutional characteristics of the audit, such as legal and legal - organizational, which will allow us to obtain a complete structure of the audit as an integral culturalhistorical, socio-economic and legal phenomenon. The question arises why we are talking here about the institutional characteristics of the audit, and not about the elements of its structure. It seems to us that any element is associated with a certain program, the so-called target component, and for institutional forms, the desire to fix the structure of any phenomenon, subject matter, regardless of the target programs, is characteristic. For example, the legal support of the audit may be different in different countries, it may change repeatedly in each particular state, but the law as a necessary part of the audit structure remains unchanged. Institutional forms must correspond to three essential characteristics: first, they must always be preserved regardless of the life of individual people; second, they should not be specifically targeted; third, they should " preserve, maintain, and reproduce a certain type of life associated with the type of content (but not the specific content)" [7].

Discussing the institutionalization of methodology, Yu. V. Gromyko, S. V. Popov, N. G. Alekseev, A. E. Levintov, and V. G. Maracha come to the conclusion that any institutional phenomenon is based on a typological, rather than a substantive, characteristic. But this, of course, does not mean that the typology can not have a specific content. The content is variable, the type is constant, since it is the core of a particular device [10].

Thus, we support the point of view of S. V. Popov that " an institution is a certain type of social structure that is reproduced every time there is a need to cultivate a certain type of meaningful life, but not the definition of programs. And these types live very long, much longer than any programs".

The institutions we have identified are filled with specific content depending on the mode of production, social relations, the peculiarities of material and spiritual culture, the geopolitical situation in the world, etc.

Institutional audit issues are issues related to social institutions that are relevant to the audit. Such typological characteristics of audit include institutions of economics, politics, financial control, stock market, public and professional associations, law, etc. [2, 4].

The methodological significance of the institute and institutional mediation is great in the field of any scientific knowledge, including audit. From our point of view, the concept of "institution" in the field of auditing is to be interpreted broadly, that is, not only as an isolated group of legal rules governing economic relations, but the relations regulated by these rules (for example, bankruptcy Institute), as well as the organization of the process in which these relations are carried out (bankruptcy or financial analysis on the subject of bankruptcy).

\section{Results}

We consider the most important institution of audit - law in its specific typological aspect. Legal issues of audit are primarily related to the relationship between public and private law principles in the audit activity. This situation arose due to the fact that in the context of the development of market relations, there was an urgent need to find the optimal legal 
form of the relationship between the state and civil society in order to realize the interests of all participants in the legal process. The abundance of different points of view of Russian legal experts on the essence of audit is a real confirmation of the vagueness of this legal form in Russian legislation. It seems to us that the problem lies not only in the vagueness of the wording (for example, the attribution of audit activities to business), but also has deeper roots, determined by the essence of the entire legal system of the Russian state . [3].

The fact is that legal science has long developed the concept of legal sources of law as sources in the formal sense of the word, that is, derived from the branches of government. In this regard, there are legislative sources, subordinate, judicial, and international legal sources. This list, as a rule, is exhausted, and this is nothing more than the nationalization of law, leaving aside the norms of civil society.

In the Russian Federation, attempts have been made to combine the normative selforganization of society with the public sphere, which, in our opinion, makes the public sphere more open, transparent and will further contribute to more effective interaction between civil society and the state .

Audit activity, which is located at the intersection of public and private legal interests, is the opposite of the process of nationalization of law. It cannot be implemented without the implementation of both public and private legal norms: agreements, contracts, corporate norms, etc. Of course, public law and private law norms cannot and should not coincide, since their functions are different, resulting from the very nature and scope of the public relations regulated by these norms, but they can and should effectively complement each other.

The Federal Law " On Auditing in the Russian Federation " was the basis for further regulation of auditing activities, the legal status of individual auditors and audit organizations, but a number of its provisions today need to be improved. In this regard, the most important are the general theoretical and applied tasks of forming a legislative framework that is adequate to the current conditions of the market economy.

At this period of development of the company, when adopting new regulations governing relations in a particular area of economic activity, they often refer to the need to bring Russian and world practices closer together, and not only. However, given the significant differences between our economy and the economy of developed countries, we can say that this process will be quite long.

It should be noted that the audit in all countries is strictly regulated, but the question of what the role of the state in this process is solved in different ways.

In the world practice, there are two different concepts of regulating audit activities. Thus, in countries with a continental system of law - such as Austria, Spain, France, Germany, etc., there is mainly a detailed regulation of accounting, financial accounting and reporting, where the main user is the state. It is these features that form the corresponding audit concept. In these countries, the authorized state bodies establish the rules for conducting audit activities, fixing them in regulatory legal acts.

The second concept of regulating audit activity is developed in the countries of the Anglo-Saxon system of law (USA, Canada, Great Britain, Australia, etc.) and involves the orientation of auditors to meet the needs of shareholders, investors and other business participants. In these countries, historically, a different approach to the regulation of audit activities has developed, which is mainly carried out by public audit associations. An example is the American Institute of Chartered Public Accountants and Auditors. This American professional organization creates and adjusts professional standards.

All the main accounting and auditing bodies in the UK are united in the company SSAV, which represents the interests of the main users of audited financial documents.

It should be noted that the countries of the European Union have taken a number of measures to bring together national legal norms in the field of audit. So, in April 1984, the 
so-called VIII Directive was adopted, which unified the minimum requirements for persons and citizens of these states who are allowed to carry out audit activities.

If we consider the relationship of the audit concept with the improvement of the audit legislation in Russia, then it is necessary to justify specific proposals for its improvement. In addition, when we talk about the improvement of legislation in a particular activity, we usually mean the improvement of all by-laws and regulations based on this legislation. This is directly related to the audit activity.

Currently, Russia is working hard to establish a domestic audit. At the same time, the potential of audit activity in our country remains far from fully realized, and the audit opportunities in achieving the goals of financial control are almost not exhausted. And the reason for this is the unresolved issue of the optimal ratio of state regulation and selfregulation of audit activities $[9,11]$.

In this regard, the problem of determining the status of audit decisions (standards, opinions) is acute. The Russian Federation belongs to the states with a statutory legal system, where audit decisions (standards, opinions) should play the role of acts of application of law. However, the development of market relations in Russia persistently displaces audit in the sphere of civil society activity, frees it from excessive guardianship by the state and assumes a gradual transformation into public audit associations that will independently create and adjust professional standards. This is not seen as a "dilution" of the legal system of the Russian state, but rather as its strengthening through the transfer of certain functions to public associations, without which it is impossible to have an effective civil society.

It should be noted that one of the reasons that prompted the Government to adjust the law on auditing is the desire to significantly improve the quality of audit services while reducing audit risk.

The main changes provided for in the new legislative document are aimed at developing self-regulation of the audit profession, clarifying the functions of the state in regulating audit activities and introducing supervision over the development of the audit profession [5].

As already noted, in today's form, the Russian audit is not able to solve the tasks associated with a significant increase in the reliability of the reports. The main reason lies in the sole dominance of the administrative lever.

Researchers-economists "impose" regulators on the economic sphere and recognize four types of regulation: state, co-regulation (business and government), delegated coregulation, and voluntary co-regulation

The reforms carried out at the present stage are based on the American method of deregulation. However, in Russia, this happens on the basis of" resetting " state functions and transferring them to self-regulating companies (SROs), which are designed to solve all issues of improving the quality of audit.

In this case, experts say, radical and fundamental solutions are needed. The mandatory rotation of audit organizations by an economic entity and the separation of the audit business from the consulting business are at best half-measures.

I would like to emphasize that at first the draft law on SRO was planned as a document aimed at implementing a unified state policy to protect the interests of business entities, which would allow to weaken the state regulation of audit activities while increasing the influence of the public component in the regulatory system .

In the recent dozens of years, the collapse of major companies such as ENRON, Worldcor, Parmalat, etc., and the role of auditors in these scandals have not only been publicly reported, but also contributed to a major revision of the self-regulation of the audit profession worldwide, to significant changes in the regulatory framework, awareness of the need for regulation and its improvement as a whole and also of existing surveillance 
systems in particular.

Moreover, in 2013-2015, 16 Russian auditors overlooked the problem banks. RBC has compiled a rating of auditors who issued positive opinions to banks, for which this conclusion was the last (table 1):

Table 1. Russian most significant auditors rating.

\begin{tabular}{|c|c|c|c|c|}
\hline Auditors & $\begin{array}{c}\text { Number of } \\
\text { opinions }\end{array}$ & $\begin{array}{c}\text { Revenue } \\
\text { million } \\
\text { rubles }\end{array}$ & $\begin{array}{c}\text { Expenses } \\
\text { million } \\
\text { rubles }\end{array}$ & Audited banks \\
\hline 1.Banks-Expert & 8 & 3.4 & 3.5 & $\begin{array}{l}\text { «Russian Credit". AMB } \\
\text { Bank. "Tula Industrialist". } \\
\text { "Retail Lending Company". } \\
\text { "Universal Credit". Bank-T }\end{array}$ \\
\hline $\begin{array}{l}\text { 2.Listik and } \\
\text { Partners }\end{array}$ & 7 & 16.5 & 16.6 & $\begin{array}{l}\text { provincial bank "Simbirsk". } \\
\text { Aldanzolotobank. } \\
\text { "Uralliga". Your personal } \\
\text { bank. Ecoprombank }\end{array}$ \\
\hline 3. Prio-Audit & 5 & 23.5 & 16.4 & $\begin{array}{l}\text { Smolensky Bank. Askold. } \\
\text { Smolevich» }\end{array}$ \\
\hline $\begin{array}{l}\text { 4.Yekaterinburg } \\
\text { Audit Center }\end{array}$ & 4 & 28.7 & 26.7 & $\begin{array}{l}\text { Volzhsky Social Bank. } \\
\text { Tyumenagroprombank }\end{array}$ \\
\hline $\begin{array}{l}\text { 5. Board of Tax } \\
\text { Consultants }\end{array}$ & 4 & $\begin{array}{c}\text { No data } \\
\text { available }\end{array}$ & $\begin{array}{c}\text { No data } \\
\text { available }\end{array}$ & $\begin{array}{ll}\text { "Client". } & \text { "Gagarinsky". } \\
\text { Master-Bank } & \\
\end{array}$ \\
\hline 6 Cestris-audit & 4 & 8.3 & 7.8 & $\begin{array}{l}\text { Angibank. a new } \\
\text { commercial bank }\end{array}$ \\
\hline $\begin{array}{l}\text { 7.Intercom- } \\
\text { Audit }\end{array}$ & 3 & 81.4 & 82.2 & $\begin{array}{l}\text { Project Finance Bank. M } \\
\text { Bank }\end{array}$ \\
\hline $\begin{array}{l}\text { 8.Norm- } \\
\text { Profaudit }\end{array}$ & 3 & 23.5 & 9.5 & $\begin{array}{l}\text { Ogni Moskvy. European } \\
\text { Industrial Bank }\end{array}$ \\
\hline 9. Finexpertiza & 3 & 443.5 & 409.5 & $\begin{array}{l}\text { IstCom-Finance. Investment } \\
\text { Bank }\end{array}$ \\
\hline 10.Audit Center & 2 & $\begin{array}{c}\text { No data } \\
\text { available }\end{array}$ & $\begin{array}{c}\text { No data } \\
\text { available }\end{array}$ & Volga-Kama Bank \\
\hline 11. Mian & 2 & $\begin{array}{c}\text { No data } \\
\text { available }\end{array}$ & $\begin{array}{c}\text { No data } \\
\text { available }\end{array}$ & Fininvest. Master Bank \\
\hline $\begin{array}{l}\text { 12.Slavyansk- } \\
\text { Audit }\end{array}$ & 2 & $\begin{array}{l}\text { No data } \\
\text { available }\end{array}$ & $\begin{array}{l}\text { No data } \\
\text { available }\end{array}$ & Gelendzhik-Bank \\
\hline $\begin{array}{l}13 \mathrm{FBK} . \\
\text { Finance }\end{array}$ & 2 & $\begin{array}{c}\text { No data } \\
\text { available }\end{array}$ & $\begin{array}{c}\text { No data } \\
\text { available }\end{array}$ & Euromet. Intrastbank \\
\hline $\begin{array}{l}\text { 14.Evaluation } \\
\text { and Audit } \\
\text { Center }\end{array}$ & 2 & $\begin{array}{l}\text { No data } \\
\text { available }\end{array}$ & $\begin{array}{l}\text { No data } \\
\text { available }\end{array}$ & Trust Republican Bank \\
\hline $\begin{array}{l}\text { 15.Central } \\
\text { Bank-Audit }\end{array}$ & 2 & $\begin{array}{c}\text { No data } \\
\text { available }\end{array}$ & $\begin{array}{c}\text { No data } \\
\text { available }\end{array}$ & Naftabank \\
\hline $\begin{array}{l}\text { 16.Economy - } \\
\text { Audit of NN }\end{array}$ & 2 & $\begin{array}{c}\text { No data } \\
\text { available }\end{array}$ & $\begin{array}{c}\text { No data } \\
\text { available }\end{array}$ & PC-Bank \\
\hline
\end{tabular}

In this regard, there is such a problem of audit as its legal assessment. As is well known, the legal assessment of phenomena, facts, and processes is dictated by the immediate practical demands of public life, but despite the increased interest of researchers in this category, much of its characterization remains problematic. "So, to date, the question of what constitutes a legal assessment is not resolved: a subjective or objective phenomenon, what is its nature (reflective or cognitive)," notes A. A. Novichenko [4].

A.A. Nuikin says in this regard: "You can approach objectivity as close as you want, but it is impossible to cover it. And reduce it by separating a part of it for the convenience of 
knowledge, too. Infinity divided by any number gives infinity. Therefore, subjectivity is not a part of objectivity, but a transformed objectivity. Subjectivity is the only way to objectivity in its cognition". Nevertheless, the majority of Russian legal scholars believe that it is impossible to limit the essential characteristics of a legal assessment only to the framework of legal (in particular, criminal) qualifications. Evaluative concepts, from the point of view of law, are also characteristic of the law-making process - in the interpretation of legal norms. They are most clearly manifested in the activities of experts, when special knowledge is used as a type of legal assessment. An audit in its own way is a financial, budgetary, tax, corporate, and legal assessment in its broadest sense in the language of legal definitions. For example, the issue of determining the insolvency and insolvency of an enterprise, as well as issues of deliberate bankruptcy, cannot do without an audit that can reliably determine the economic and financial condition of the enterprise, tax evasion, redistribution of property among new shareholders, illegal transactions during the period of the enterprise's activity, etc.

It is possible to distinguish criminal-legal, civil-legal, corporate-legal aspects of the assessment in the activities of the auditor. The latter is the least developed in the legal literature, since the corporate-legal aspect of the assessment is most often perceived as an attempt to avoid criminal and civil liability. This, in our opinion, is a negative manifestation of the nationalization of law, which interferes with the balance of state and private-right interests.

In Article 6 of the law" On Auditing in the Russian Federation "No. 307-FZ, the legislator of the Federation provides that" the auditor's report is a document intended for users of financial (accounting) statements, audited entities and contains the auditor's opinion expressed in the prescribed form on the reliability of financial (accounting) statements and compliance of the accounting procedure with the legislation of the Russian Federation". Thus, the law does not consider the auditor's report as evidence, and in the Code of Criminal Procedure of the Russian Federation and the Administrative Code of the Russian Federation there are no references to the auditor's report as evidence at all [6].

The blank standards in the audit tend to be more dispositive than imperative standards. The problem, in our opinion, is that the federal legislator, who establishes dispositive audit rules in relation to materiality, did not pay attention to the fact that, for example, materiality or materiality criteria that determine the reliability of information should be attributed to mandatory standards, as well as a set of significant indicators for each specific group of users. A set of essential indicators in relation to different groups of users should be attributed to dispositive norms.

This means that those elements or categories of audit that form the structure of the materiality model that is necessary for the recognition of the financial statements as legally reliable or unreliable are considered mandatory. This suggests that the absence of elements that are recognized as mandatory indicates that there are gaps in the materiality model that lead to uncertainty in the recognition of the financial statements as reliable. The consolidation of mandatory elements of materiality at the federal level prevents the determination of the same reporting as reliable or unreliable, depending on different methods of determining materiality or the professional judgment of auditors.

Making the elements of materiality imperative means an unconditional obligation to establish each such element in the universal model of materiality, and also clearly reflects the strict requirement of the law on the parametric characteristics of the elements of materiality, the change of which is either impossible or permissible, but must be within the limits established by federal rules.

The criteria of materiality, as its elements, even within the same user group may be different. But fixing the materiality criterion at the federal level will allow the user to make managerial or economic decisions based on the legally fixed level. 
In scientific works and, as a result, in regulatory legal acts, the same reporting indicators are called both basic and essential. Discussing the significance of this issue in relation to the tax and its elements, M. Yu. Berezin, in particular, writes: "In our opinion, the difference between the concepts of "basic" and "essential" is not quite clear, that is, it is not clear what the difference between the main and essential elements of the tax is. If these concepts equally denote the same phenomenon, then this can only indicate a refusal to apply a verified scientific approach to the classification of tax elements and an unwillingness to use uniform terminology to describe the relevant processes and phenomena, since the methods of scientific research, characterized by the rigor and clarity of approaches, do not allow for vague conclusions, and the duality of the terminology used. For example, in the Appendix to the standard "Materiality and Audit Risk", a set of basic indicators for determining materiality, rather than essential ones, was recommended.

The methodological importance of this issue lies in the fact that the federal legislator is called upon to regulate the main audit issues, without identifying the essential indicators with the basic ones. In the introduction of this paper, we have already discussed materiality as the most important category of audit. Therefore, materiality and its criteria should be the basis of federal legislation. At the same time, materiality is an imperative norm, leaving no room for the auditor to choose, but the imperativeness of the rule of law does not mean the same consequences for all legal entities implementing this norm. If for the auditor, materiality is the criterion for the validity of its conclusion, then for the users of the information in the financial statements, materiality is the basis for changing the management decision. The auditor himself, as a realizer of the law, when determining materiality in the audit, brings his own vision (we have already written about this, considering the audit as an evaluative legal concept). In this connection, materiality as an important category of audit should be reflected in the federal legislation on audit.

Thus, the audit should be based on mandatory rules that have the same meaning for all legal entities, but possibly different consequences. It seems to us that materiality as a category of audit should be imperative in its content for both auditors and users of information about financial statements. However, as we have already noted above, the set of significant indicators for different groups of users may be different and may be dispositive in nature. The implementation of the information obtained during the audit cannot be unified, which is due to the fact that the legal entities pursue different goals and interests. In addition, for some users, the certainty of actual information is important, while for others, forecast values, trends and prospects are of interest.

Therefore, the problem of imperativeness and dispositivity of the norms of law in the field of audit is a reflection of the objective position of the audited financial statements, in which the interests of both the state and civil society are concentrated. The implementation of these interests is possible in the following way: the state establishes the audit framework, implemented through the application of materiality and its criteria that unify their application, and civil society sets its own rules for the use of audited information. As a result, the state and public audit functions are effectively combined. The problem of imperativeness and dispositivity of legal norms in the field of audit that we have raised is directly related to the problem of existing gaps in federal legislation.

In order to fill in the gaps in the legislation, it is necessary to unify materiality as a criterion for the reliability of financial statements.

\section{Conclusions}

1. In the context of the development of market relations, there is an urgent need to find the optimal legal form of the relationship between the state and civil society in order to realize the interests of all participants in the audit process. 
The development of market relations in Russia persistently displaces audit from the sphere of state regulation to the sphere of civil society activity. The convergence of the normative self-organization of society with the public sphere of the state will make the audit more open and transparent and will further promote more effective interaction between civil society and the state in the field of economic relations.

2. Systematization of the regulatory regulation of audit activity in Russia, determination of the hierarchy of legislative and regulatory acts, the degree of their development, identification of gaps in them allows us to determine the real level of its managerial impact on public relations at various levels.

3. Legal assessment - a key aspect of the audit, which is a specific, cognitive, practical action process for active reflection, understanding and fixing the social significance of the objects in the language of the legal definitions of compliance with both substantive and procedural law, and with the application of scientific concepts, skills, practical skills and experience.

In general, we can conclude that the role of legal assessment in modern audit is as follows: 1) it is not specified by the legislator, 2) it is specified in the process of law enforcement, 3) it gives the law enforcement officer the opportunity of free discretion, free assessment of factors.

The legislator can not do without evaluative concepts for reasons of imperfect legal technology, the presence of gaps in scientific knowledge. Thus, the auditor, applying evaluative concepts, provides users, taking into account the specifics of a particular situation, to assess the actual situation, the opinion of which has already been expressed by the auditor.

4. The most important institutional problem of audit is the dispositivity and imperativeness of the norms of law in its sphere. This is the result of the objective position of the audited financial statements, which focus on public and private legal principles that reflect the interests of the rule of law and civil society. It seems that the audit should be based on mandatory rules established by the state and having the same meaning for all legal entities. The implementation of audit in the field of civil society is mainly associated with dispositive norms that determine the freedom of choice of users of audit information in making economic decisions.

5. Thus, the role of audit in the system of state control and society is specified in its institutions: imperativeness and dispositivity, audit responsibility, legal assessment, and the mechanism for implementing audit legislation. The identification of institutional audit problems and their solution will optimize the process and results of audit activities.

\section{References}

1. Y. Treshchevsky, V. Voronin, M. Melnik, A. Sokolov, Journal Studies In Systems, Decision And Control 135, 81-93 (2018) Doi: 10.1007/978-3-319-72613-7_7

2. T. Gogoleva, P. Kanapukhin, I. Lyashenko, V. Yaryshina, M. Melnik, Advances In Intelligent Systems and Computing 622, 581-590 (2018) Doi: 10.1007/978-3-31975383-6_74

3. S. Stepanov, Journal Economic Policy 14, 34-53 (2019) Doi: 10.25018/0236-14932020-31-0-602-613

4. Y. Bakhturin, Journal Mining Information And Analytical Bulletin (Scientific And Technical Journal) 3-1, 602-613 (2020) Doi: 10.18288/1994-5124-2018-5-24-49

5. A. Frenkel, Y. Sergienko, B. Tikhomirov, A. Surkov, Journal Economic Policy, 13-5 24-49 (2018) Doi: 10.17976/Jpps/2018.05.11 
6. N. Tikhonova, Journal The Policy. Political Research 5, 134-149 (2018) Doi: 10.23683/2073-6606-2019-17-1-96-111

7. D. Kadochnikov, Journal Terra Economicus 17(1), 96-111 (2019) Doi: 10.23683/20736606-2019-17-1-96-111

8. A. Fedyunina, Y. Averyanova, Journal Economic Policy 13-6, 102-121 (2018) Doi: 10.18288/1994-5124-2018-6-102-121

9. D. Kolesnikova, Journal Vestnik of Saint Petersburg University. Philosophy And Conflict Studies 35(4), 563-568 (2019) Doi: 10.21638/Spbu17.2019.403

10. A. Sinyavsky, Electronic Scientific And Educational Journal " History" 8(82) (2019) Doi: 10.18254/S207987840006045-8

11. A. Burenin, Journal Economic Policy 14(1), 76-91 (2019) Doi: 10.18288/1994-51242019-1-76-91 